\title{
FOUR NEW SPECIES OF ACALYPHA (EUPHORBIACEAE) FROM MALESIA
}

\author{
VERNIE G. SAGUN \& GEOFFREY A. LEVIN \\ Illinois Natural History Survey, 1816 South Oak St., Champaign, IL 61820, USA; and \\ Department of Plant Biology, University of Illinois at Urbana-Champaign, USA; \\ e-mail: glevin@inhs.uiuc.edu
}

\section{SUMMARY}

Four new species of Acalypha from the Malesian region, A. argentii, A. balgooyii, A. floresensis and A. pulogensis are described and illustrated.

Key words: Euphorbiaceae, Acalypha, Malesia.

\section{INTRODUCTION}

In the course of revising Acalypha L. (Euphorbiaceae) for Flora Malesiana, we have discovered four new species from Sulawesi, Buru and Flores in Indonesia, and in Luzon, Philippines. With about 450 species worldwide (Webster, 1994; Radcliffe-Smith, 2001) and its inherent taxonomic complexity (Fosberg \& Sachet, 1980), Acalypha often presents difficulty in species delimitation, also among many Malesian species. However, these four new species are distinct both morphologically and biogeographically. No attempt was made to place these new taxa in the classification system of Pax \& Hoffman (1924), which is based on homoplasious inflorescence morphology and is not supported by phylogenetic analysis based on DNA sequence data (Levin et al., 2005).

Descriptions are based on herbarium specimens. The term 'spicate' is used for simplicity to describe the staminate inflorescence, which is technically a spike-like thyrse. The term 'dots' refers to light-coloured circular patches in the epidermis that may represent druse crystals, but we have not confirmed this anatomically. We also observed paired appendages flanking the base of each foliaceous pistillate bract. Since the bracts are modified leaves, the subtending paired appendages appear to be homologous to stipules; hence we use the term 'bract stipules' for these structures.

\section{DESCRIPTION OF SPECIES}

\section{Acalypha argentii Sagun \& G. A. Levin, spec. nov. - Fig. 1}

\footnotetext{
Planta omnis pubescens. Inflorescentia bisexualis axillaris spicata interdum paniculata $50-150 \mathrm{~mm}$ longa $5-10 \mathrm{~mm}$ lata, ramis 2 vel 3 a $7-15 \mathrm{~mm}$. Pars staminata $20-35 \mathrm{~mm}$ longa c. $2 \mathrm{~mm}$ lata. Inflorescentiae bractea persistens $2-5 \mathrm{~mm}$ longa $0.2-0.5 \mathrm{~mm}$ lata. Bracteae pistilatae 5.5-6 mm longa 6-7 mm latae valde nervosae punctatae. - Typus: Meijer 10198 (holo L; iso A, BO, KY, MO, US), Indonesia, Sulawesi, Kulasi near Palu, 19 May 1975.
} 


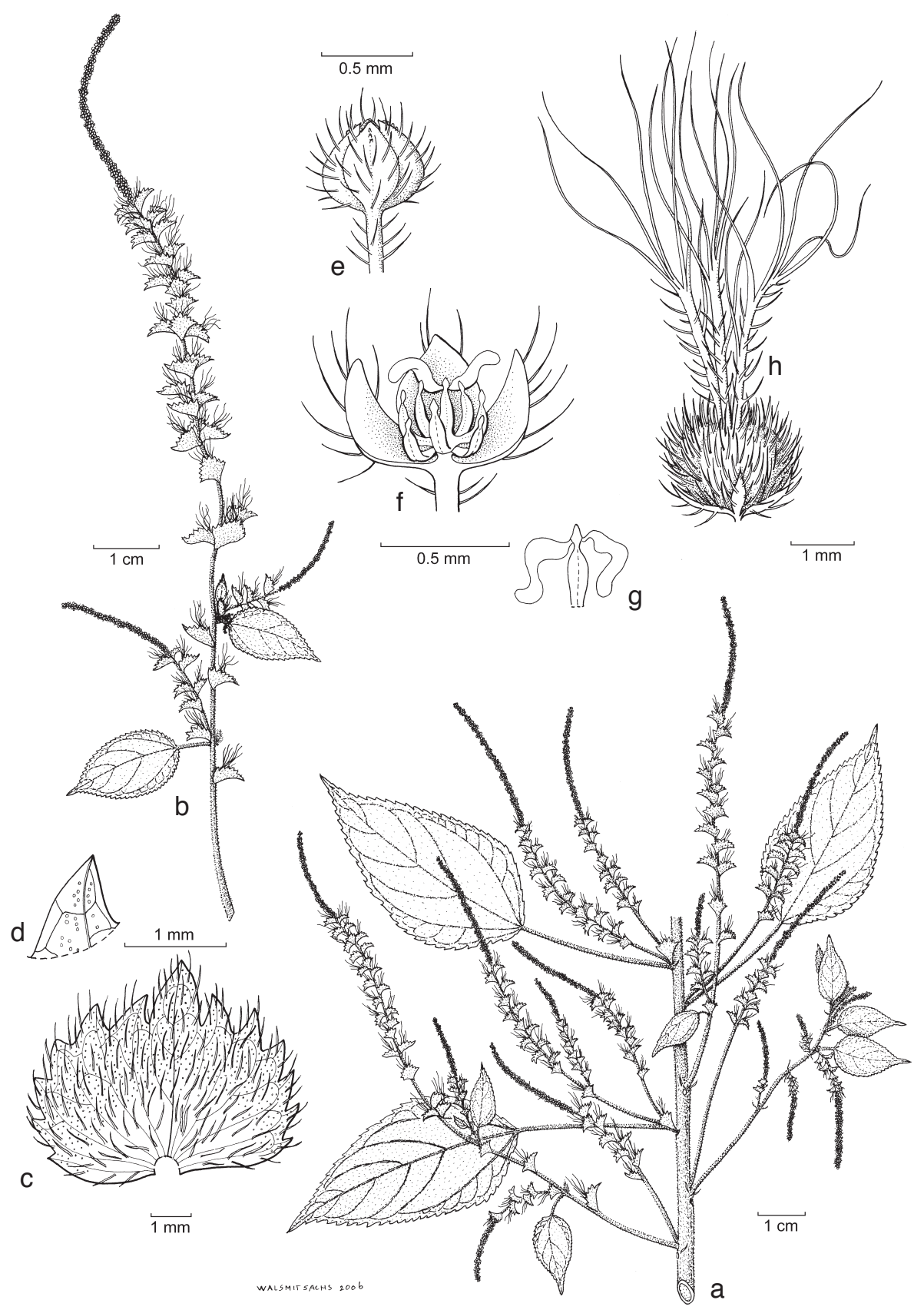

Fig. 1. Acalypha argentii Sagun \& G.A. Levin. a. Habit; b. paniculate bisexual inflorescence; c. pistillate bract; d. pistillate bract lobe showing dots; e. staminate flower showing indument; f. staminate flower showing androecium (anthers removed from all but one stamen); g. stamen; h. pistillate flower (all: Meijer 10198, L). 
Herbaceous annual, c. $0.4 \mathrm{~m}$ tall, monoecious; flowering branches c. $40 \mathrm{~cm}$ long, 2-4 $\mathrm{mm}$ diameter. Indumentum velvety, with simple recurved hairs. Stipules persistent, elliptic, $3-5$ by $0.2-0.5 \mathrm{~mm}$, with capitate trichomes c. $0.1 \mathrm{~mm}$ long. Leaves: petioles 5-40 mm long, with simple straight hairs $0.5-0.75 \mathrm{~mm}$ long; blade ovate to elliptic, 20-54 by 10-27 mm, length/width ratio 1.6-2, chartaceous, base acute to obtuse, margin serrate, lobes c. 1 by $1-2.5 \mathrm{~mm}$ with a gland on tooth tip, apex acute to acuminate, upper surface pubescent, hairs on lamina $0.25-1 \mathrm{~mm}$ long, straight, lower surface densely pubescent, veins at base triplinerved, upper secondaries 4 per side, looped and closed near margin, tertiary veins and veinlets scalariform to reticulate. Inflorescences bisexual, pistillate below and staminate above, axillary, spicate or paniculate, 50-150 by $5-10 \mathrm{~mm}$, simple to 2- or 3-branched, branches $7-15 \mathrm{~mm}$ apart, subtended by persistent bracts, elliptic, $2-5$ by $0.2-0.5 \mathrm{~mm}$, peduncle $8-15 \mathrm{~mm}$ long, sometimes a single pistillate flower at the base, hairs simple recurved, $0.2-0.5 \mathrm{~mm}$ long; pistillate portion $22-70$ by $7-10 \mathrm{~mm}$, internodes $2-10 \mathrm{~mm}$ long, bracts $11-29$; staminate portion $20-35$ by c. $2 \mathrm{~mm}$, internodes $0.5-1 \mathrm{~mm}$ long, $18-35$ nodes with c. 15 flowers per node. Staminate flowers: bracts elliptic, c. 1 by $0.25 \mathrm{~mm}$, with sparse hairs outside, $0.2 \mathrm{~mm}$ long; pedicels $0.5-0.75 \mathrm{~mm}$ long, elongating in maturity, with straight hairs, 0.1-0.5 mm long; calyx $0.5-0.75 \mathrm{~mm}$ diam., 4-lobed, sepals ovate, c. 0.5 by $0.3 \mathrm{~mm}$, with straight hairs, c. $0.2 \mathrm{~mm}$ long, midrib sparsely verrucate on upper half, apex acute; stamens 8 , filaments c. $0.25 \mathrm{~mm}$ long, thecae c. 0.25 by $0.1 \mathrm{~mm}$, pendulous. Pistillate flowers 1 or 2 per bract, maturing singly; bract stipules elliptic $0.2-0.5$ by c. $0.2 \mathrm{~mm}$; bract sessile, 5.5-6 by 6-7 $\mathrm{mm}$, strongly veined, with dots, densely hairy outside, sparsely hairy inside, with simple trichomes, $0.5-1 \mathrm{~mm}$ long, sometimes with solitary capitate trichomes c. $0.1 \mathrm{~mm}$ long on bract lobe apex and sinus; bract lobes 15 , the apical lobe c. 2 by $1.5-2 \mathrm{~mm}$, lateral lobes $0.75-1$ by $0.5-1 \mathrm{~mm}$, apices acute; pedicels 0(-0.3) mm long; calyx 1-1.5 mm diam., 3- (or 4-)lobed, sepals ovate to elliptic, c. 1 by $0.25 \mathrm{~mm}$, densely hairy on margins with sparse verrucae on upper half of midrib; ovary globose to oblate c. 0.5 by $0.75 \mathrm{~mm}$, trilocular; stigmas $3,3.5-4 \mathrm{~mm}$ long, each 4-6 divided, smooth. Fruits not seen. Allomorphic fruits not seen.

Distribution - Indonesia, Sulawesi (Central part, area of Kulasi near Palu).

Habitat \& Ecology - Altitude 700-800 m. Flowering: May.

Note - Similar to the widespread A. lanceolata Willd., but hairy all over with velvety leaves, spicate to paniculate inflorescences with longer more robust staminate portions, and female bracts that are larger and very hairy. Acalypha lanceolata has practically glabrous leaves, spicate inflorescences that are never branched and have short staminate portions, and pistillate bracts that are comparatively smaller and practically glabrous. Acalypha argentii is a rare species from Central Sulawesi and known only from the type collection. The specific epithet is assigned in honour of Dr. George Argent, former Head of Tropical Botany at the Royal Botanic Garden Edinburgh, who has done extensive floristic work in Malesia, particularly in Indonesia and the Philippines.

\section{Acalypha balgooyii Sagun \& G. A. Levin, spec. nov. - Fig. 2}

Acalyphae hainanensi similis. Lamina elliptica $6-12 \mathrm{~cm}$ longa $1.5-3 \mathrm{~cm}$ lata ratione 4-4.5, margine crenato. Bracteae staminatae ellipticae ad oblanceolatae. Inflorescentiae pistillatae pseudoscorpioideae interdum basi floribus masculis. — Typus: Nooteboom 5327 (holo L), Indonesia, NW Buru, N of Bara, Waeduna River, 29 Nov. 1984. 


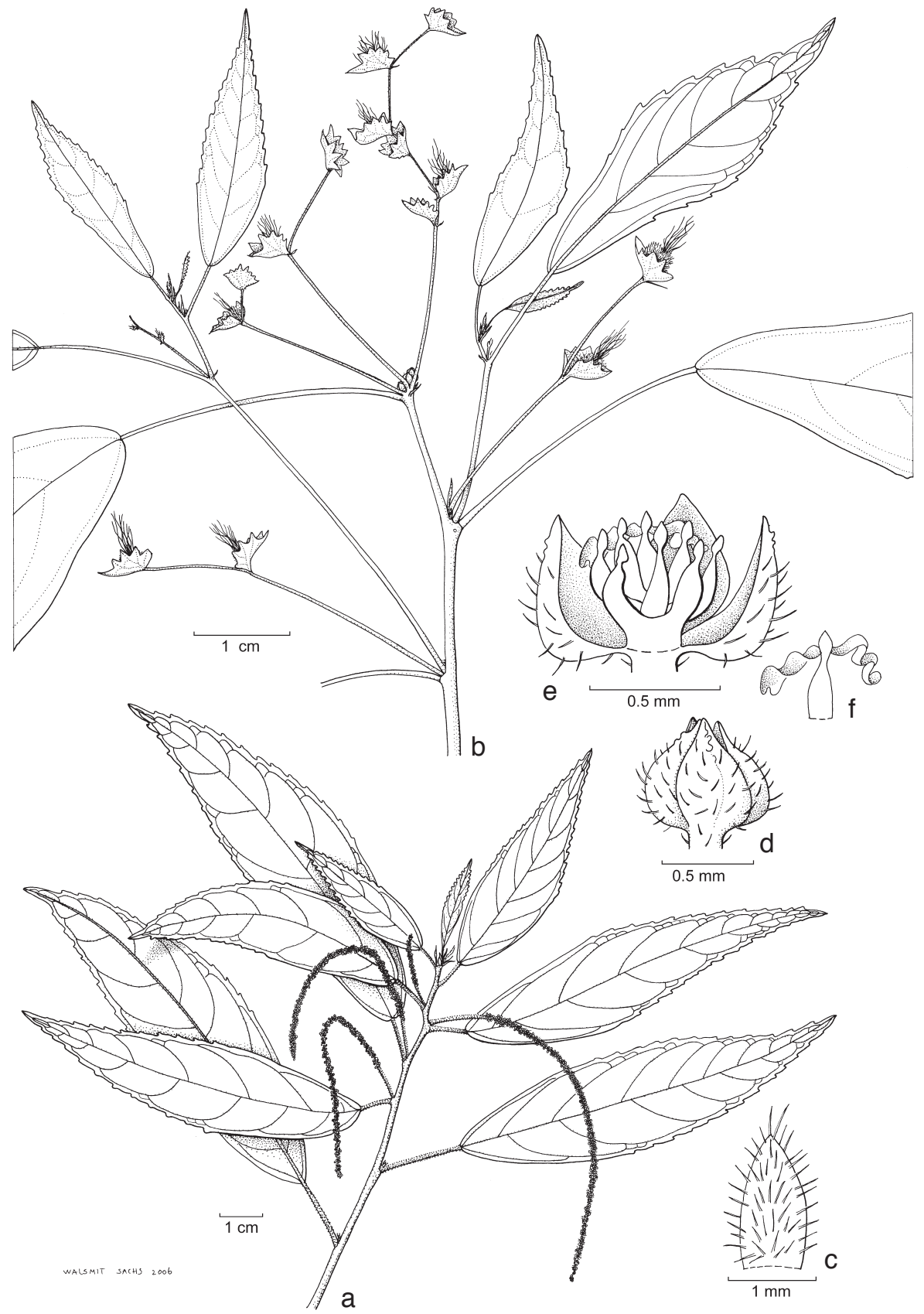

Fig. 2. Acalypha balgooyii Sagun \& G. A. Levin. a. Habit of staminate branch; b. habit of pistillate branch; c. detail of staminate bract; d. staminate flower showing indument; e. staminate flower showing androecium (anthers removed from most stamens); f. stamen (a, c: Van Balgooy 4861, L; b, d-f: Nooteboom 5327, L). 
Shrub, c. $1 \mathrm{~m}$ tall, fertile branches exclusively male or with female inflorescences, sometimes bearing some male flowers at their bases; flowering branches $30-36 \mathrm{~cm}$ long, 2-3 mm diameter. Indumentum nearly absent, except simple straight hairs on young parts. Stipules caducous, ovate to elliptic, $1.75-2$ by $0.3-0.5 \mathrm{~mm}$, midrib hairy, with short stalked trichomes. Leaves: petioles $1-3 \mathrm{~cm}$ long; blade elliptic $6-12$ by $1.5-3$ $\mathrm{cm}$, length/width ratio 4-4.5, chartaceous, base obtuse to acute; margin crenate, lobes $0.5-1$ by $4-5 \mathrm{~mm}$, gland 1 per tooth tip, apex acuminate, upper and lower surfaces glabrous, veins at base triplinerved, upper secondaries 7-9 per side, looped and closed near margin, tertiary veins scalariform, veinlets reticulate. Staminate inflorescences axillary, spicate and hairy, peduncle 4-7 mm long, indument simple straight hairs, up to $0.2 \mathrm{~mm}$ long, fertile portion $2.5-10$ by $1.5-2 \mathrm{~cm}$, densely flowered when young, internodes 1-1.5 mm long, rachis and peduncle hairy. Staminate flowers: bracts elliptic to obovate, c. 0.75 by $0.25-0.3 \mathrm{~mm}$, with dense hairs outside, $0.1-0.25 \mathrm{~mm}$ long, apex acute with a gland on tip; pedicels $0.5-0.75 \mathrm{~mm}$ long, elongating in maturity, with straight hairs, up to $0.2 \mathrm{~mm}$ long; calyx $0.5-0.75 \mathrm{~mm}$ diam., 4-lobed, sepals ovate, c. 0.5 by $0.25 \mathrm{~mm}$, with straight hairs, $0.1-0.2 \mathrm{~mm}$ long, midrib verrucate on upper third, apex acute; stamens 8 , filaments c. $0.25 \mathrm{~mm}$ long, thecae c. 0.25 by 0.1 $\mathrm{mm}$, pendulous. Pistillate inflorescences axillary, peduncle 1-2 cm long, sometimes with a few male flowers at the base; indument nearly absent, fertile portion spicate, pseudoscorpioid, 25-40 by 4-7 mm, internodes 7-12 mm long. Pistillate flowers 1 per bract; bract stipules elliptic c. 0.75 by $0.2 \mathrm{~mm}$; bract sessile, $5-6$ by $8-11 \mathrm{~mm}$, strongly veined outside, with dots, nearly glabrous outside and inside, with capitate trichomes, up to $0.1 \mathrm{~mm}$ long on margin; bract lobes $9-11$, apical lobe $2-3$ by $1.5-2 \mathrm{~mm}$, lateral lobes $0.75-1.5$ by $0.75-1 \mathrm{~mm}$, apices acute; pedicel absent; calyx $1-1.5 \mathrm{~mm}$ diam., 3-lobed, sepals ovate, c. 0.75 by $0.75 \mathrm{~mm}$, sparsely hairy outside with no verrucae, glabrous inside; ovary globose to oblate, c. 1 by $1 \mathrm{~mm}$, trilocular; stigmas 3,3-5 mm long, each 7-9 divided, smooth. Fruits globose to oblate, 2.5 by $3.5 \mathrm{~mm}$, distal half covered with inconspicuous glandular trichomes, columella 1.5-1.75 mm long. Seeds prolate, c. 2 by $1.5 \mathrm{~mm}$, patterning indistinct; caruncle less than half of seed length. Allomorphic fruits unknown.

Distribution - Indonesia, NW Buru, N and SE of Bara, Waeduna River.

Habitat \& Ecology - Riverine forest; in river valley with steep slopes. Limestone mixed with gravel and stones. Altitude 100-300 m. Flowering: November.

Note - Acalypha balgooyii is endemic to Buru and similar to A. hainanensis Merr. \& Chun in terms of having elliptic leaves and crenate margins, but differing in its exclusively staminate inflorescence or pistillate pseudoscorpioid inflorescence, sometimes with a few male flowers at the base of the leaf axil where the pistillate inflorescence is attached. Unlike A. hainanensis, A. balgooyii does not exhibit pistillate flowers at the base of the predominantly staminate inflorescences. It is also notable that the staminate plants also exhibit reddish petioles. A paratype is assigned: Van Balgooy 4861 (para L; isopara A, BO, KY, MO, US), Indonesia, NW Buru, SE of Bara, Waeduna River, 22 Nov. 1984. The specific epithet is assigned in honour of M.M.J. van Balgooy, one of the world's experts on Malesian plants. 
3. Acalypha floresensis Sagun \& G. A. Levin, spec. nov. - Fig. 3

Folium infra velutinum. Bracteae pistillatae distincte petiolatae 1-2 mm longae. - Typus:

Loeters 1846 (holo L), Indonesia, Flores, Lesser Sunda Islands.

Shrub or tree, plant sexuality unknown, only pistillate branches seen; flowering branches c. $15 \mathrm{~cm}$ long, c. $3 \mathrm{~mm}$ diameter. Indumentum velvety, with simple recurved hairs. Stipules persistent, linear, c. 4 by $0.75 \mathrm{~mm}$, with straight hairs, $0.5-0.75 \mathrm{~mm}$ long, without capitate trichomes. Leaves: petioles $3-6 \mathrm{~cm}$ long; blade elliptic, $8-10.5$ by $4-5.5 \mathrm{~cm}$, length/width ratio $1.9-2$, chartaceous; base acute to slightly obtuse; margin serrate, lobes $1.5-2$ by $3-4 \mathrm{~mm}$, no glands on tooth tip; apex acuminate, upper surface glabrous, lower surface velvety, basal veins triplinerved, upper secondaries 6 or 7 per side, looped and closed near margin, tertiary veins scalariform, veinlets reticulate. Staminate inflorescences unknown. Pistillate inflorescences axillary, peduncle 3-5 $\mathrm{cm}$ long; indumentum velvety with simple straight hairs $0.25 \mathrm{~mm}$ long; fertile portion

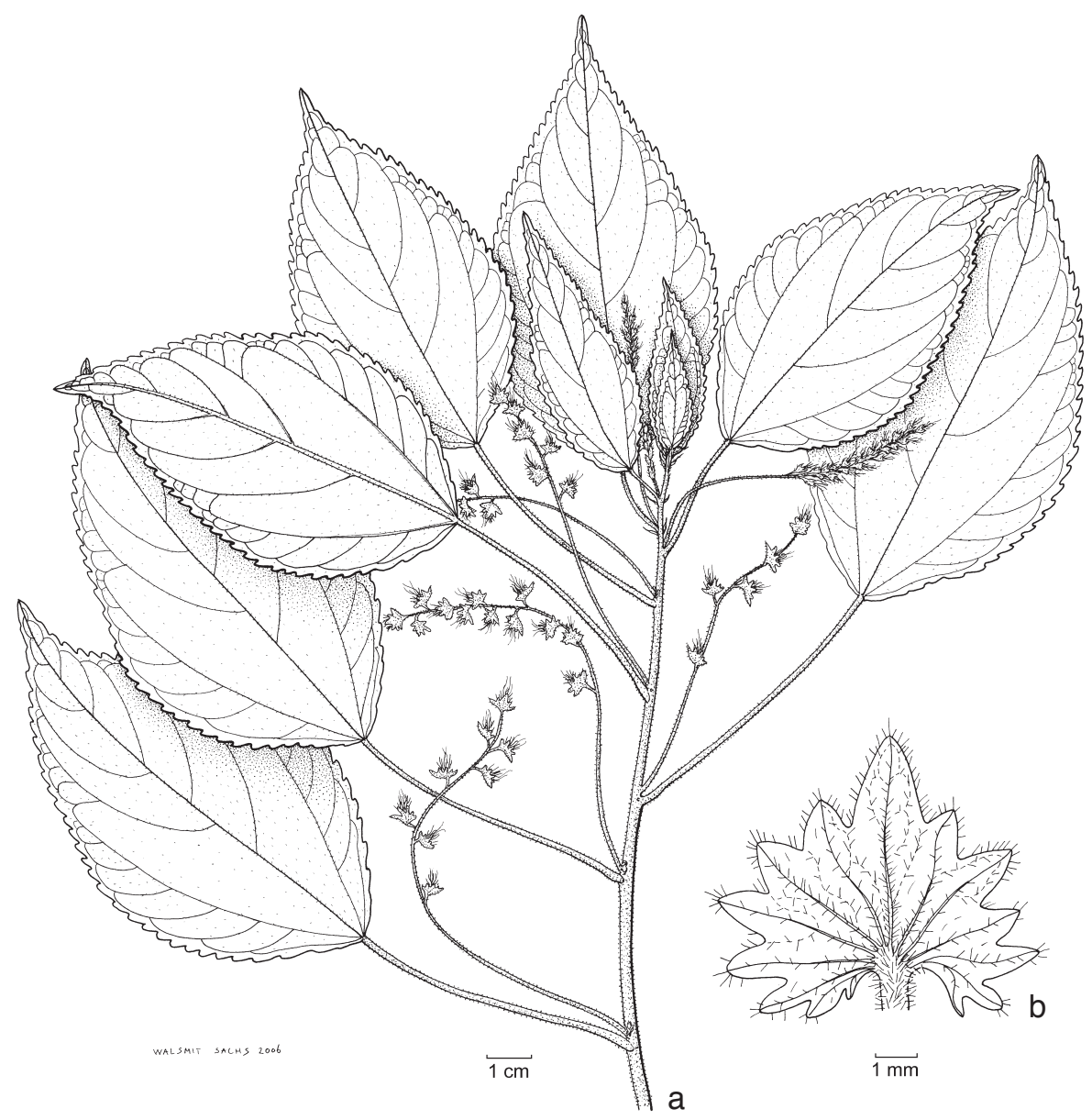

Fig. 3. Acalypha floresensis Sagun \& G.A. Levin. a. Habit; b. pistillate bract (Loeters 1846, L). 
spicate, $70-100$ by $7-10 \mathrm{~mm}$, internodes $5-11 \mathrm{~mm}$ long. Pistillate flowers 1 per bract; bract stipules not seen; bracts $4-5$ by $5-6 \mathrm{~mm}$, with a petiole $1-2 \mathrm{~mm}$ long, indistinctly veined, without dots, practically glabrous inside and outside; bract lobes 11-15, the apical lobe $1.5-2$ by $1.5-2 \mathrm{~mm}$, lateral lobes $1.5-2$ by $1-2 \mathrm{~mm}$, apices acute; calyx $0.5-1 \mathrm{~mm}$ diam., 3-lobed, sepals ovate to elliptic, c. 1 by $0.75 \mathrm{~mm}$, densely hairy on margins, glabrous inside, verrucae absent; ovary globose to oblate, $0.5-1$ by c. $1 \mathrm{~mm}$, trilocular; stigmas 3, 5-6 mm long, each 9-14 divided, smooth. Fruits globose to oblate, c. 2.5 by $3 \mathrm{~mm}$, distal half covered with glandular trichomes, columella c. 1.75 $\mathrm{mm}$ long. Seeds prolate, c. 2 by $1.75 \mathrm{~mm}$, patterning indistinct, caruncle less than half of seed length. Allomorphic fruits unknown.

Distribution - Indonesia, Flores, Lesser Sunda Islands.

Note - Acalypha floresensis, from Flores in the Lesser Sunda Islands, possesses distinctly petiolate pistillate bracts subtending the pistillate flowers. This is a distinctive character not found elsewhere in Malesian Acalypha or elsewhere in the genus as far as we are aware. Airy Shaw (1982) was the first to notice the distinctness of this specimen (Loeters 1846) and annotated it as "Acalypha inter A. grandis et A. caturus fers intermedia", probably due to the velvety hairs on the abaxial side of the leaves of A. grandis Benth. and its accrescent foliaceous bracts. The only similarity of this species to A. caturus Blume is its ovate to elliptic leaves. Acalypha caturus is distinct with its bilocular fruits and absence of foliaceous pistillate bracts.

\section{Acalypha pulogensis Sagun \& G. A. Levin, spec. nov. - Fig. 4}

Folii margo serratus ad undulatus. Bracteae pistillatae 6-12 mm longae 8-11 mm latae extus valde nervatae punctatae, lobis 11 lobo apicali maiore $4-6 \mathrm{~mm}$ longo $1.5-2 \mathrm{~mm}$ lato apice parum rotundato, lobis lateralibus $2-3 \mathrm{~mm}$ longis $1-1.5 \mathrm{~mm}$ latis apicibus acutis. - Typus: PNH (Celestino) 4372 (holo L, barcode L0242361; iso L, barcode L0241973), Philippines, Mt Pulog, Kabayan, Benguet, Luzon, 2 March 1948.

Small tree, 3-4 m tall, monoecious; flowering branches 15-28 cm long, 4-7 mm diam., indumentum velvety, with simple recurved hairs. Stipules persistent, ovate to elliptic, c. 12 by $2.5 \mathrm{~mm}$, midrib hairy, without capitate trichomes. Leaves: petioles $2-9 \mathrm{~cm}$ long; blade ovate to elliptic, $9-16.5$ by $5.5-11 \mathrm{~cm}$, length/width ratio $1.5-1.6$, chartaceous; base emarginate; margin serrate to crenate to undulate, lobes $1-3$ by $2-5$ $\mathrm{mm}$, no glands on tooth tip; apex acute to acuminate; upper surface glabrous; lower surface sparsely hairy; veins at base triplinerved, upper secondaries c. 8 per side, looped and closed near margin, tertiary veins scalariform, veinlets reticulate. Staminate inflorescences axillary, peduncle 5-10 $\mathrm{mm}$ long; indumentum simple, of velvety hairs up to $0.2 \mathrm{~mm}$ long; spicate, $4-15$ by $3-4 \mathrm{~cm}$, densely flowered, fascicles sometimes separated 1-2 mm; rachis hairy. Staminate flowers: bracts ovate, $0.75-1$ by c. $1 \mathrm{~mm}$, with dense hairs outside, $0.3-0.5 \mathrm{~mm}$ long; pedicels $0.5-1 \mathrm{~mm}$ long, elongating in maturity, with straight hairs up to $0.2 \mathrm{~mm}$ long; calyx $0.5-0.75 \mathrm{~mm}$ diam., 4-lobed, sepals ovate to elliptic, c. 0.75 by $0.5 \mathrm{~mm}$, with straight hairs up to $0.25 \mathrm{~mm}$ long, midrib not verrucate, apex acute; stamens 8 , filaments c. $0.25 \mathrm{~mm}$ long, thecae c. 0.25 by $0.1 \mathrm{~mm}$, pendulous. Pistillate inflorescences axillary, peduncle $12-40 \mathrm{~mm}$ long; indument velvety with simple recurved hairs $0.5-0.75 \mathrm{~mm}$ long; spicate, $110-170$ by $12-20 \mathrm{~mm}$, internodes $3-10 \mathrm{~mm}$ long. Pistillate flowers 1 or 2 per bract, maturing 


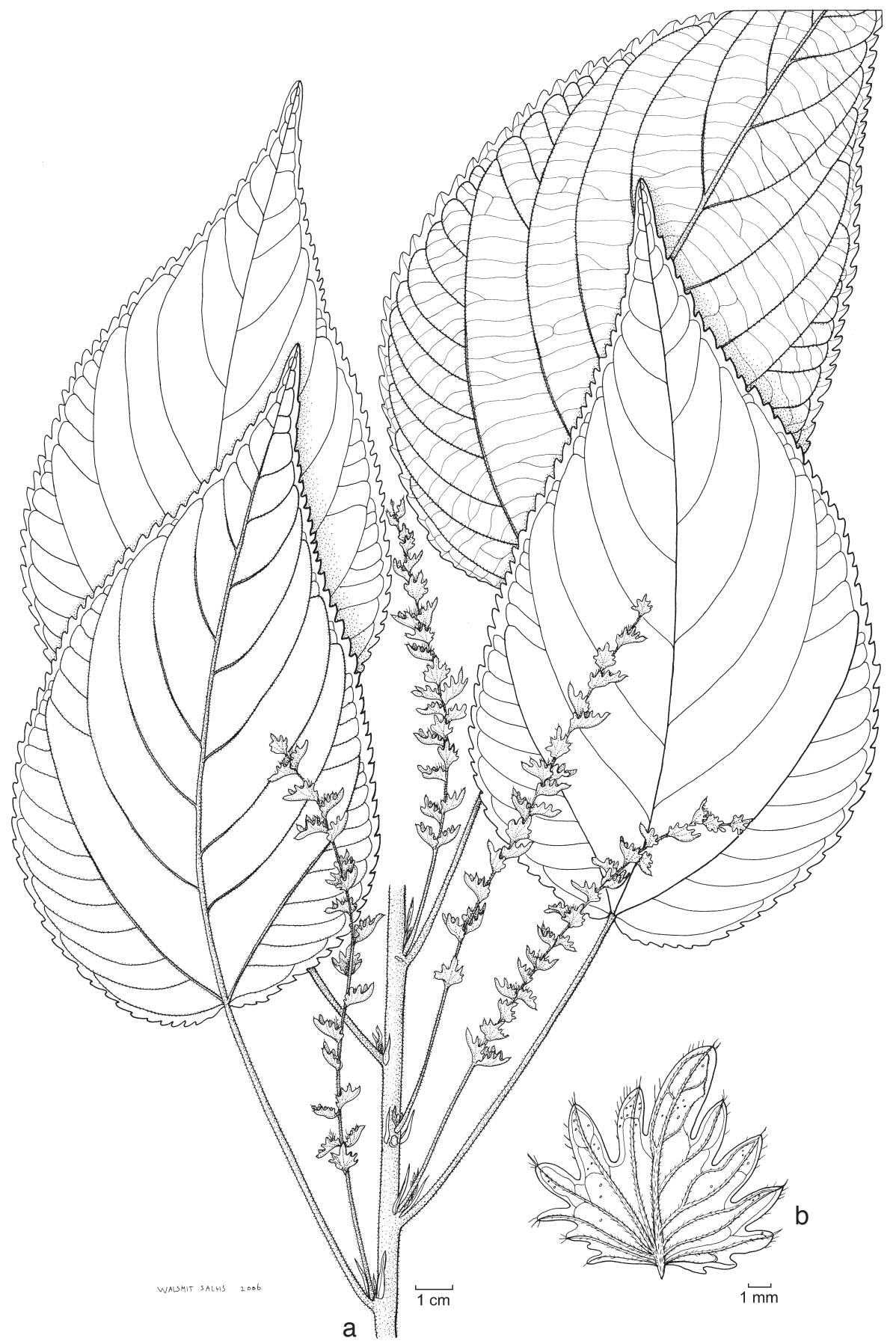

Fig. 4. Acalypha pulogensis Sagun \& G.A. Levin. a. Habit; b. pistillate bract (PNH (Celestino) 4372, L). 
singly; bract stipules elliptic, $0.75-1$ by $0.3-0.5 \mathrm{~mm}$; bracts sessile, $6-12$ by $8-11 \mathrm{~mm}$, strongly veined outside, with dots, sparsely hairy outside, glabrous inside, $0.5-0.75$ $\mathrm{mm}$ long; bract lobes 11 , apical lobe $4-6$ by $1.5-2 \mathrm{~mm}$ with slightly rounded apex, lateral lobes $2-3$ by $1-1.5 \mathrm{~mm}$, apices acute; pedicels $0(-0.75) \mathrm{mm}$ long; calyx $1-1.5$ mm diam., 3-lobed, sepals ovate to elliptic, c. 1.25 by $1 \mathrm{~mm}$, hairy outside with no verrucae, glabrous inside; ovary globose to oblate c. 1 by $1 \mathrm{~mm}$, trilocular; stigmas 3, 5-6 mm long, each 4-6 divided, smooth. Fruits globose to oblate, c. 1.75 by 1.75 $\mathrm{mm}$, distal half covered with glandular trichomes, columella c. $0.75 \mathrm{~mm}$ long. Seeds prolate, c. 1.75 by $1 \mathrm{~mm}$, patterning indistinct; caruncle covering less than upper half of seed. Allomorphic fruits unknown.

Distribution - Philippines, Luzon, Mountain Province, Mt Pulog.

Habitat \& Ecology - Altitude c. 2000 m. Flowering: March.

Note - Acalypha pulogensis is known only from a single collection from Mt Pulog, Luzon, Northern Philippines. Merrill and Quisumbing distributed the specimens with an unpublished name. However, we decided not to use this name due to its misleading connotation of obtuse or undulate leaf margins, whereas the leaves are often serrate. This new species is closely related to A. angatensis Blanco with its thick staminate inflorescences, and to A. amentacea Roxb. in terms of its deeply toothed pistillate bracts and large practically glabrous stipules. However, A. pulogensis does not possess the velvety leaf abaxial sides and the boat-shaped stipules of $A$. angatensis. The new species also has much larger, deeply lobed pistillate bracts with dots, as opposed to the smaller pistillate bracts of its close allies.

\section{ACKNOWLEDGEMENTS}

We are thankful to Peter van Welzen (L) for his support in our treatment of Acalypha for Flora Malesiana, Anita Walsmit Sachs-Jansen (L) for her beautiful illustrations, Jan Frits Veldkamp (L) for the Latin diagnoses, and Rick Phillippe (ILLS) and Kenneth Robertson (ILLS) for curatorial support and advice. VGS is also grateful for the support from the Illinois State Academy of Sciences Student Research Award, and the University of Illinois at Urbana-Champaign Dissertation Travel Grant. This work is also supported by NSF grant DEB-0128872 to Geoffrey A. Levin and Victor W. Steinmann.

\section{REFERENCES}

Airy Shaw, H.K. 1982. The Euphorbiaceae of Central Malesia (Celebes, Moluccas, Lesser Sunda Is.). Kew Bull. 37: 1.

Fosberg, F.R. \& M.-H. Sachet. 1980. Systematic studies of Micronesian plants. Smithsonian Contr. Bot. 45: 1-40.

Levin, G. A., V.W. Steinmann \& V.G. Sagun. 2005. Phylogeny and biogeography of Acalypha (Abstract), XVII International Botanical Congress, Vienna, Austria: 68.

Pax, F. \& K. Hoffmann. 1924. Euphorbiaceae-Crotonoideae-Acalypheae-Acalyphinae, Additamentum VII. In: A. Engler (ed.), Das Pflanzenreich IV.147.xvi (Heft 85): 1-231. Engelmann, Leipzig.

Radcliffe-Smith, A. 2001. Genera Euphorbiacearum. Royal Botanic Garden, Kew.

Webster, G.L. 1994. Synopsis of the genera and suprageneric taxa of Euphorbiaceae. Ann. Missouri Bot. Gard. 81: 33-144. 